\title{
Yatay Sıcak Su Tanklarında Tank İçerisine Eğik Konumlandırılmış Engel Yerleştirmenin Etkisinin Sayısal Olarak İncelenmesi
}

\section{Numerical Investigation of the Effect of Placing Sloped Obstacle in the Horizontal Hot Water Tanks}

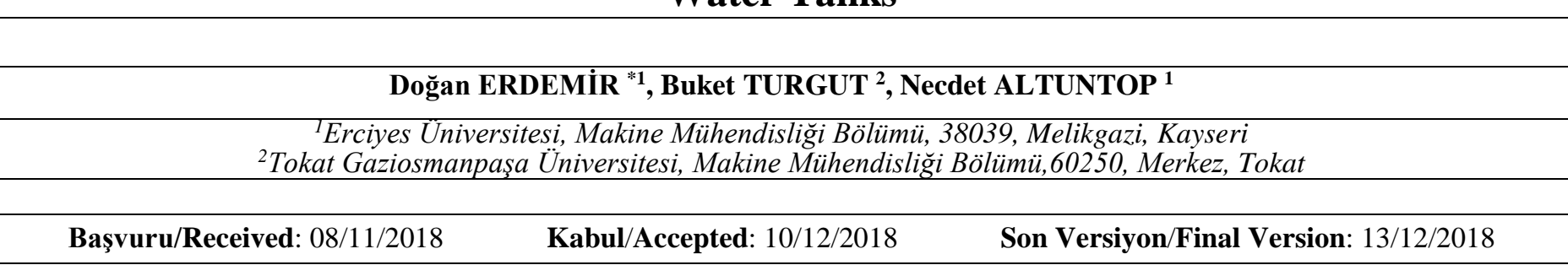

Öz

Güneş enerjili sıcak su sistemlerinde yatay sıcak su tanklarının kullanımı vakum tüplü güneş kolektörlerinin kullanımının artması ve daha estetik bir görünüm sağlamasından dolayı yaygınlaşmaktadır. Artan kullanımına karşın yatay sıcak su tankları ile alakalı literatürde kısıtlı sayıda çalışma bulunmaktadır. Bu çalışmada, bir yatay mantolu sıcak su tankının ısıl performansını arttırmak için tank içerisine eğik konumlandırılmış engel yerleştirmenin etkisi sayısal olarak araştırılmıştır. Engeller şebeke girişinden $\mathrm{m}=50,100$ ve $150 \mathrm{~mm}$ mesafelerde ve yatayla $\mathrm{a}=60^{\circ}, 75^{\circ}$ ve $90^{\circ}$ açı yapacak şekilde yerleştirilmiştir. Böylece engel eğiminin ve konumunun etkisi sayısal olarak incelenmiştir. Sonuçlar; tank içerisindeki sıcaklık dağılımı, manto çıkış ve kullanım suyu sıcaklıkları, ortalama depolanan su sıcaklığı, enerji ve ekserji verimleri üzerinden verilmiştir. Çalışmanın sonucunda, engel yerleştirilen her durumun, içerisinde engel olmayan duruma göre daha yüksek ısıl performansa sahip olduğu görülmüştür. Termodinamik açısından en iyi durum $\mathrm{a}=60^{\circ}$ ve $\mathrm{m}=100 \mathrm{~mm}$ olduğu durumda elde edilmiştir. Aynı durumda depolama sıcaklığ $135^{\circ} \mathrm{C}$ olup, engelsiz tanka göre yaklaşık $4^{\circ} \mathrm{C}$ daha yüksektir. Yine aynı durumda manto çıkış sıcaklığı engelsiz tanka göre daha düşük, şebeke çıkış sıcaklığı ise daha yüksektir. Sonuç olarak; tank içerisinde eğik konumlandırılmış engel yerleştirme, içerisinde engel bulunmayan ve dik engel bulunan duruma göre daha yüksek ısıl performans sağlamıştır.

\section{Anahtar Kelimeler}

"Yatay sıcak su tankı, Güneș enerjili sıcak su sistemi, Duyulur ısıl enerji depolama".

\begin{abstract}
The use of horizontal hot water tanks in solar hot water systems is becoming widespread due to the increased use of vacuum tube solar collectors and providing a more aesthetic appearance. Despite the increasing use of it, there are a limited number of studies in the literature regarding horizontal hot water tanks. In this study, the effect of placing sloped obstacle in the tank to increase the thermal performance of a horizontal mantle hot water tank was investigated numerically. The obstacle has been located at a distance of $\mathrm{m}=50,100$ and $150 \mathrm{~mm}$ from the mains input and at an angle of $\mathrm{a}=60^{\circ}, 75^{\circ}$ and $90^{\circ}$. Thus, the effect of the slope angle and position has been investigated numerically. Results have been evaluated based on temperature distribution within the tank, mantle outlet and main outlet temperatures, average temperature of stored water, energy and exergy efficiencies. As a result of the study, every situation where the obstacle is placed in the tank has a higher thermal performance than the ordinary tank. The best condition in terms of thermodynamics is seen in case of $\mathrm{a}=60^{\circ}$ and $\mathrm{m}=100 \mathrm{~mm}$. In the same case, the storage temperature is $35^{\circ} \mathrm{C}$ and is approximately $5^{\circ} \mathrm{C}$ higher than the ordinary tank. In the same case, the mantle outlet temperature is lower than the ordinary tank and the outlet temperature is higher. As a result; The sloped obstacle placement in the tank provides higher thermal performance than the obstacle in which there is no obstacle and the vertical obstacle.
\end{abstract}

\section{Key Words}

"Horizontal hot water tank, Solar domestic hot water system, Sensible thermal energy storage” 


\section{GíRiș}

Yenilenebilir enerji kaynakları doğası gereği sürekli olarak aktif olmayan kaynaklardır. Bu sebepten enerji kaynağının aktif olmadığı zamanlarda enerji kaynağından yararlanmaya devam etmek için uygulanabilecek en elverişli yöntemlerden biri enerji depolamadır. Bu duruma ek olarak, enerji kullanımında arz ve talep arasında da ciddi uyumsuzluklar vardır. Enerjinin yoğun kullanıldığı dönemlerde enerji üretimi ihtiyacı karşılamamakta ya da enerjinin az kullanıldığı dönemlerde üretilen enerji boşa gitmektedir. Bu sebepten dolayı, enerji kaynaklarından yararlanırken farklı enerji tüketim tarifeleri (pik dönem, pik olmayan dönem, gündüz, gece vb.) uygulanmaktadır. Enerji tüketiminin yoğun ve pahalı olduğu dönemlerdeki enerji ihtiyacını enerji kullanımının yoğun olmadığı ve ucuz olduğu dönemlere kaydırmak için de enerji depolama sistemlerinden yararlanılabilir. Böylece enerjinin üretildiği ve tüketildiği dönemler arasındaki farklılıklar kaydırılmış olur. Ayrıca enerji depolama sistemleri sayesinde enerji dönüşüm sistemlerinden, makinalardan ya da cihazlardan daha verimli yararlanılabilir. Enerji; her bir enerji türünde depolanabilir. Acar (2018) enerji depolama türleri arasında bir karşılaştırma ve derecelendirme çalışması yapmıştır. Bu çalışmadan görüldüğü üzere, 1sıl enerji depolama yaygınlık ve gelişmişlik açısından en iyi durumda olan enerji depolama türlerinden biridir. Ayrıca 1sıl enerji depolamanın yaygın olarak kullanılmasındaki en önemli nedenlerden biri de dünyada kullanılan enerjinin büyük bir kısmının ısı olarak üretilmesi ve tüketilmesidir. Geçmişten günümüze 1sıl enerji depolamanın çok sayıda farklı uygulaması geliştirilmiş ve uygulanmıştır. Yenilenebilir enerji kaynaklarından yararlanma açısından ve 1sıl enerji depolama uygulaması olarak en eski ve olgunlaşmış uygulamalardan biri güneş enerjili sıcak su sistemleridir. Şekil 1'de tipik bir güneş enerjili sıcak su sisteminin görüntüsü verilmektedir. Şekil 1'den görüldüğü üzere, bu sistemlerde güneş enerjisi güneş kolektörlerinde 1sı enerjisine dönüştürülerek kolektörden geçen iş akışkanına aktarılır. Kolektörlerde 1sıtılan bu iş akışkanını (su ise) direk kullanmak mümkün olabileceği gibi bir depolama ortamında depolanabilir ya da bir 1sı değiştiriciyle sahip olduğu 1sı enerjisi başka bir ortama aktarılabilir. Kolektörde üretilen sıcak suyun direk ya da bir değiştirici aracılığı ile depolanmasıyla elde edilen sıcak sudan güneş olmadığı zamanlarda da yararlanmak mümkün olmaktadır.

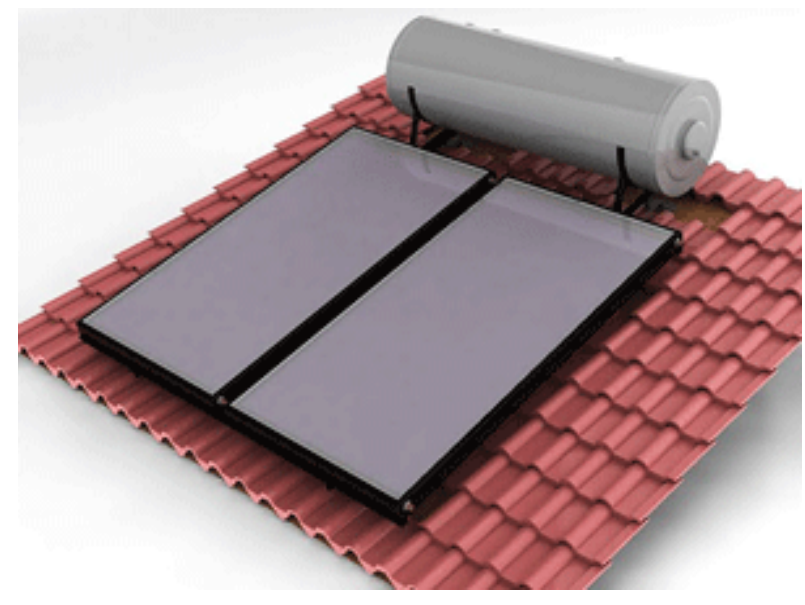

Şekil. 1. Tipik bir güneş enerjili sıcak su sisteminin görünümü

\begin{tabular}{ll}
\multicolumn{2}{l}{ Terminoloji } \\
A & Manto girişi \\
a & Engel açısı $\left(^{\circ}\right)$ \\
B & Manto çıkışı \\
C & Şebeke girişi \\
C & özgül 1sı $(\mathrm{J} / \mathrm{kg} \mathrm{K})$ \\
$\mathrm{D}$ & Şebeke ç1kış1 \\
$\mathrm{E}$ & Enerji $(\mathrm{J})$ \\
$\mathrm{Ex}$ & Ekserji $(\mathrm{J})$ \\
$\mathrm{I}$ & Ekserji yok oluşu $(\mathrm{J})$ \\
$\mathrm{m}$ & Engelin şebeke girişinden olan mesafesi $(\mathrm{mm})$ \\
$\dot{m}$ & kütlesel debi $(\mathrm{kg} / \mathrm{s})$ \\
$\mathrm{T}$ & Sicaklık $\left(\mathrm{K},{ }^{\circ} \mathrm{C}\right)$ \\
$\eta$ & Enerji verimi \\
$\psi$ & Ekserji verimi
\end{tabular}

Güneş enerjili sıcak su sistemlerinde, güneşin aktif olmadığı gece saatlerinde güneş enerjisinden yararlanmaya devam etmek için sıcak su depolama tankları kullanılmaktadır. Gün içerisinde elde edilen sıcak su, sıcak su tanklarında daha sonra kullanılmak üzere bekletilmektedir. Sıcak su tanklarının çok sayıda türü ve sınıflandırılma şekli vardır. Ancak bu sınıflandırma şekillerinden en yaygın olanı tankın duruş pozisyonu ile alakalı olan yatay ve düşey tanklardır. Literatürdeki çalışmalardan, sağladıkları daha yüksek sıcaklık tabakalaşması derecesinden dolayı düşey sıcak tanklarının daha yüksek 1sıl performansa sahip olduğu bilinmektedir. Ancak, vakum tüplü güneş kolektörlerinin yaygın bir şekilde kullanılmaya başlaması ve görsel açıdan daha estetik 
olmasından dolayı yatay sıcak su tanklarının kullanımı gün geçtikçe artmaktadır. Artan kullanımına karşın literatürde yatay sıcak su tankları ile alakalı kısıtlı sayıda çalışma bulunmaktadır.

Andres ve Lopez (2002) yatay mantolu sıcak su içeren bir güneş enerjili sıcak su sistemi için TRNSYS modeli geliştirmişler ve bu modeli deneysel bulgular ile doğrulamışlardır. Alizadeh (1999) yatay mantolu sıcak su tankında giriş faktörlerinin tanktaki sıcaklık tabakalaşması üzerindeki etkisini sayısal ve deneysel olarak araştırmışlardır. Helva vd. (1995) yatay sıcak tanklarında sıcak su kullanımının tank içerisindeki sıcaklık dağılımı üzerindeki etkisini belirlemek için deneysel bir çalışma gerçekleştirmişlerdir. Çalışmada tank içerisindeki sıcaklık tabakalaşması üzerinde önemli etkiye sahip parametreleri belirlemişlerdir. Morrison vd. (1998) yatay mantolu sıcak su tanklarının ısıl karakteristiğini belirlemek için deneysel bir çalışma gerçekleştirmiştir. Çalışmalarında prizmatik bir tank kullanarak tank içerisindeki akım çizgilerinin nasıl olduğunu araştırmışlardır. Khalifa ve Mehdi (1999) bir yatay sıcak su tankındaki sıcaklık dağılımını elde etmek için bir boyutlu bir model ortaya koymuşlardır. Çalışmada radyal ve eksenel yöndeki sıcaklık değişimlerinin ihmal edileceğini ve tank içerisindeki sıcaklık dağılımı belirlemek için tank merkezindeki düşey sıcaklık değişiminin kullanılabileceğini belirmişlerdir. Kalogirou ve Papamarcou (2000) TRNSYS kullanarak yatay sıcak su içeren bir termosifon güneş enerjisi sistemini modellemişler ve bu modeli deneysel çalışma ile doğrulamışlardır. Morrison vs. (1999) yatay mantolu sıcak su tanklarındaki ortalama 1sı geçişi miktarını belirlemek için bir korelasyon ortaya koymuşlardır. Rosengarten vd. (1999) prizmatik bir mantolu sıcak su tankındaki akış karakteristiğini belirlemek için akış görüntüleme tekniği ile deneysel bir çalışma gerçekleştirmişlerdir. Bu çalışmada ayrıca 1sı geçişi miktarını belirlemek için bir korelasyon da ortaya konmuştur. Young ve Baughn (1981) yatay sıcak su tanklarının 1sıl karakteristiğini incelemek için sayısal ve deneysel çalışma yapmışlardır. Çalışmalarında bir boyutlu bir sayısal ortaya koymuşlar ve bu modeli deneysel çalışmalar ile doğrulamışlardır. Çalışmada eksenel sıcaklık değişiminin hesaplamalarda ihmal edileceğini vurgulamışlardır. Rosengarten vd. (2001) yatay mantolu sıcak su tankındaki 1sı geçişini belirlemek için bir model geliştirmişlerdir. Geliştirilen bu model tank içerisindeki Nusselt sayısı için geometrik şartlara ve sınır şartlarına bağlı korelasyon sunmaktadır. Zerrouki vd. (2002) yatay sıcak su tankı içerisindeki doğal taşınımla ısı geçişini belirlemek için deneysel ve teorik bir çalışma gerçekleştirmişlerdir. Liu vd. (2002) yatay tek sıcak su tankı içeren bir güneş enerjili sıcak su sistemindeki 1sı geçişini araştırmışlardır. Atmane vd. (2003) yatay 1sıtılmış bir silindir etrafındaki ısı geçişini ve doğal taşınımı incelemişlerdir. Tripanagnostopoulos and Souliotis (2004) yatay silindiril bir sıcak su tankı içeren güneş enerjili sıcak su sisteminde tankın konumunun etkisini araştırmışlardır. Tripanagnostopoulos and Souliotis (2004) 6 farklı reflektör geometrisinin sicak su depolama üzerindeki etkisini incelemişlerdir. Madhlopa vd. (2005) ikili yatay sıcak su tankı içeren güneş enerjili sıcak su sistemindeki sıcaklık tabakalaşmasını belirlemek için deneysel bir çalışma gerçekleştirmişlerdir. Jannatabadi (2012) yatay sıcak su tanklarındaki karışma etkisinin ısıl performans üzerindeki davranışını deneysel olarak incelemişlerdir. Jannatabadi ve Taherian (2012) yatay mantolu sıcak su tanklarındaki ısıl karakteristiği araştırmışlardır. Tankın ısıl performansı için önem arz eden akış debisi, 1sıl kısa devre, ortalama sıcaklık, ortalama 1sı geçiş katsayısı ve giriş hızının etkileri irdelenmiştir. Fertahi vd. (2018) vakum tüplü güneş kolektörü ve yatay sıcak su tankı içeren bir güneş enerjili sıcak su sisteminde optimum tank geometrisini belirlemek için deneysel çalışma gerçekleştirmişlerdir. Çalışmada vakum tüp sayısının depolanan su sıcaklığında önemli etkiye sahip olduğunu ve laminer akış bölgesinin artan vakum tüp sayısı ile yok olduğunu ortaya koymuşlardır. Erdemir ve Altuntop (2018) yatay mantolu bir sıcak su tankında tank içerisine akım yönüne dik engel yerleştirmenin etkisini deneysel olarak araştırmıştır. Çalışmanın sonucunda yatay mantolu sıcak su tanklarında tank içerisine akım yönüne dik engel yerleştirmenin tankın ısıl performansını iyileştirdiği bulunmuştur. Erdemir (2018) yatay mantolu sıcak tanklarında tank tasarımının tankın ısıl performansı üzerindeki etkisini sayısal olarak araştırmışlardır. Çalışmada yüksek depolama performansı için tank çapının tank boyuna oranının düşük tutulması gerektiği belirtilmiştir. Arslan ve Yaman (2017) güneş enerjili sıcak su sistemlerinin Türkiye'nin farklı şehirleri için başlangıç maliyeti ve enerji tüketim maliyeti üzerinden PSO/HJ hibrit algoritmasını kullanarak optimizasyonunu gerçekleştirmişlerdir.

Yatay sıcak tanklarının kullanımı; vakum tüplü güneş kolektörlerinin yaygınlaşması ve daha estetik görünüm sunmasından dolayı her geçen gün artmaktadır. Artan kullanımına karşın literatürde yatay sıcak su tankları ile alakalı kısıtlı sayıda çalışma bulunmaktadır. Sıcak su depolarında en önemli performans değerlendirme kriteri sıcaklık tabakalaşmasıdır. Yatay sıcak su tanklarında düşeydeki mesafe düşey tanklara göre çok daha düşük olduğundan sıcaklık tabakalaşmasının derecesi de düşüktür. $\mathrm{Bu}$ yüzden yatay sıcak su tanklarının sıcaklık tabakalaşması ve dolayısı ile 1sıl performans açısından iyileştirilmesi gerekmektedir. Literatürde yatay sıcak su tanklarında akım yönüne dik engel yerleştirme ile alakalı yapılan çalışmalardan tankın 1sıl performansını arttırdığı görülmektedir. Bu çalışmada diğer çalışmalardan farklı olarak, bir yatay mantolu sıcak su tankında tank içerisinde eğik konumlandırılmış engel yerleştirmenin etkisi sayısal olarak araştırılmıştır. Tank içerisine yatay düzlemle farklı derecelerde açı yapacak şekilde tek engel yerleştirilmiştir. Engeller ayrıca tank içerisinde şebeke girişinden itibaren farklı konumlarda yerleştirilmiştir. Böylece hem engel konumunun hem de açısının etkisi sayısal olarak araştırılmıştır. Eğik engel kullanımının etkisi dik engel yerleştirilen tankla ve içerisinde engel olmayan normal tankla kıyaslanmıştır. Sonuçlar tank içerisindeki sıcaklık dağılımı, şebeke çıkış ve manto çıkış sıcaklıkları, ortalama depolanan su sıcaklığı, enerji ve ekserji verimlilikleri üzerinden değerlendirilmiştir. 


\section{MATERYAL VE METOT}

\subsection{Yatay Mantolu Sicak Su Tankının Detayları}

$\mathrm{Bu}$ çalışmada, güneş enerjili sıcak su sistemi uygulamalarında yaygın olarak kullanılan ticari bir yatay mantolu sıcak su tankı modellenmiştir. Yatay mantolu sıcak su tankının şematik olarak gösterimi Şekil 2'de görülmektedir. Şekil 2'den görüldüğü üzere, sıcak suyun depolandığı hacmin üzerinde manto olarak adlandırılan halkasal bir hacim bulunmaktadır. Kolektörden gelen 1sı transferi akışkanı mantodan geçerek; sahip olduğu 1sı enerjisini depolama hacmindeki soğuk suya aktarır. Mantolu sıcak su tankları aynı zamanda mantolu ısı değiştiricisi olarak da adlandırılmaktadır. Güneş enerjili su 1sıtma sistemlerinde manto ve kolektör çeviriminde 1sı transferi akışkanı olarak genellikle antifriz çözeltisi kullanılmaktadır. Bu sayede tank, kış koşullarında da kullanılabilmekte ve donmaya karşı sistemi korumaktadır. Tankın iç çapı $400 \mathrm{~mm}$ boyu ise $1000 \mathrm{~mm}$ 'dir. Manto boşluğu ise 20 mm'dir. Manto iç tankın tamamını kapsamaktadır. Yani tank uzunluğu ile manto uzunluğu eşittir. Tankın depolama hacmi 196 l'dir. Bu çalışmada tankın ısıl performansını iyileştirmek için tankın iç tarafına engeller yerleştirilmiştir. Engeller tankın içerisine engelin uç kısmı ile tankın şebeke girişinden " $m$ " mesafesinde ve tankın yatay ekseni ile "a" açısını yapacak şekilde yerleştirilmiştir. Tankın ölçüleri, engellerin yerleştirildiği konumlar ve engel açıları Tablo 1'de verilmiştir.

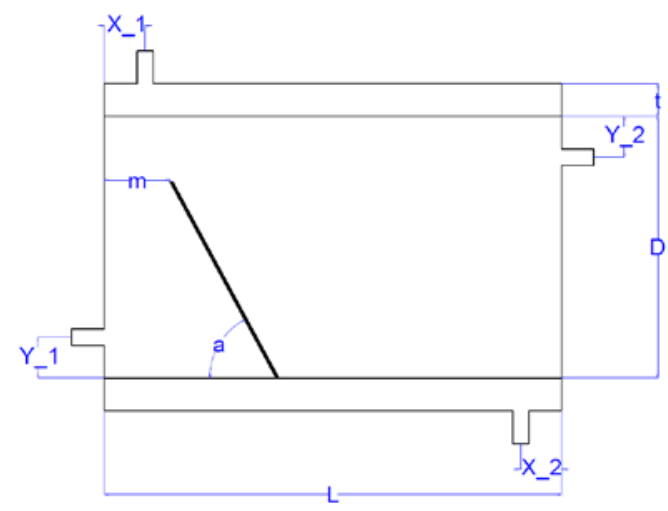

Şekil. 2. Yatay mantolu sıcak su tankının şematik gösterimi

Tablo 1. Yatay mantolu sıcak su tankının ölçüleri

\begin{tabular}{ll}
\hline İç tank çapp (D) & $400 \mathrm{~mm}$ \\
Tank uzunluğu (L) & $1000 \mathrm{~mm}$ \\
Manto boşluğu (t) & $20 \mathrm{~mm}$ \\
Giriş ve çıkış portlarının konumları $\left(\mathrm{X}_{1}, \mathrm{X}_{2}, \mathrm{Y}_{1}, \mathrm{Y}_{2}\right)$ & $50 \mathrm{~mm}$ \\
Engel tank kenarından mesafesi (m) & $50,100,150 \mathrm{~mm}$ \\
Engel yatay eksenle yaptığı açı (a) & $60^{\circ}, 75^{\circ}, 90^{\circ}$ \\
\hline
\end{tabular}

\subsection{Sayısal Model}

Şekil 2 ve Tablo 1'de detayları verilen yatay mantolu sıcak su tankı ANSYS Workbench 17.1 programı ve alt modülleri kullanılarak sayısal olarak modellenmiştir. Şekil $3^{\prime} \mathrm{de} a=60^{\circ}$ ve $\mathrm{m}=50 \mathrm{~mm}$ için sayısal model görülmektedir. Sayısal modeller 3 boyutlu oluşturulmuştur. Tankın katı kısımları modellenmemiş̧ir, sadece akışkan hacimleri modellenmiştir. Engeller iç tank hacminden engel hacmi çıkartılarak modellenmiştir. Şekil 3'de görülen sayısal model ilk olarak Solidworks 2017 programında 3 boyutlu olarak çizilmiş daha sonra Workbench programının Geometry alt modülü ile sayısal modele hazır hale getirilmiştir. Daha sonra Workbench programının Mesh alt modülü kullanılarak sayısal model sonlu sayıda hacme bölünerek ağ yapısı (mesh) oluşturulmuştur. Ağ yapısındaki eleman sayısı (eleman boyutu) sayısal çözümleme üzerindeki önemli etkiye sahiptir. Eleman sayısının çözüm üzerindeki etkisini yok etmek için ağ yapısı (grid) bağımsızlığı çalışması uygulanmıştır. Büyük eleman boyutundan düşük eleman boyutuna farklı eleman boyutları için sayısal çözümlemeler yapılmıştır. İç tank ile manto arasındaki temas yüzeyindeki akışı ve 1sı geçişini daha hassas modellemek için temas yüzeylerinde normal eleman boyutuna göre \%50 daha küçük boyutta eleman kullanılmıştır. Sırası ile 30, 20, 15, 10 ve $5 \mathrm{~mm}$ eleman boyutları denenmiştir. $15 \mathrm{~mm}$ eleman boyutundan daha sonra çözümde önemli bir değişiklik olmadığından eleman boyutu $15 \mathrm{~mm}$ olarak ayarlanmıştır. Sayısal modellerde yaklaşık olarak 3.2 milyon eleman bulunmaktadır. $a=75^{\circ}$ ve $\mathrm{m}=150 \mathrm{~mm}$ olan durum için ağ yapısının görünümü Şekil 4'de verilmiştir. 


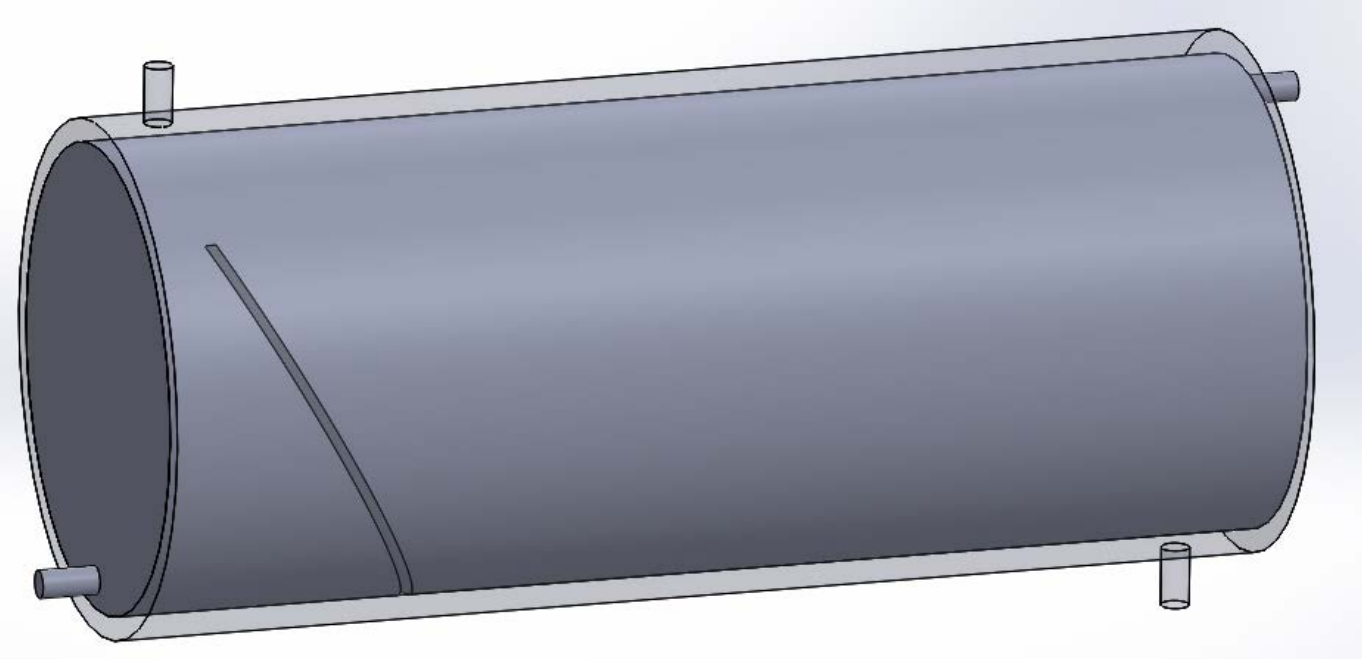

Şekil. 3. Yatay mantolu sıcak su tankının sayısal modeli
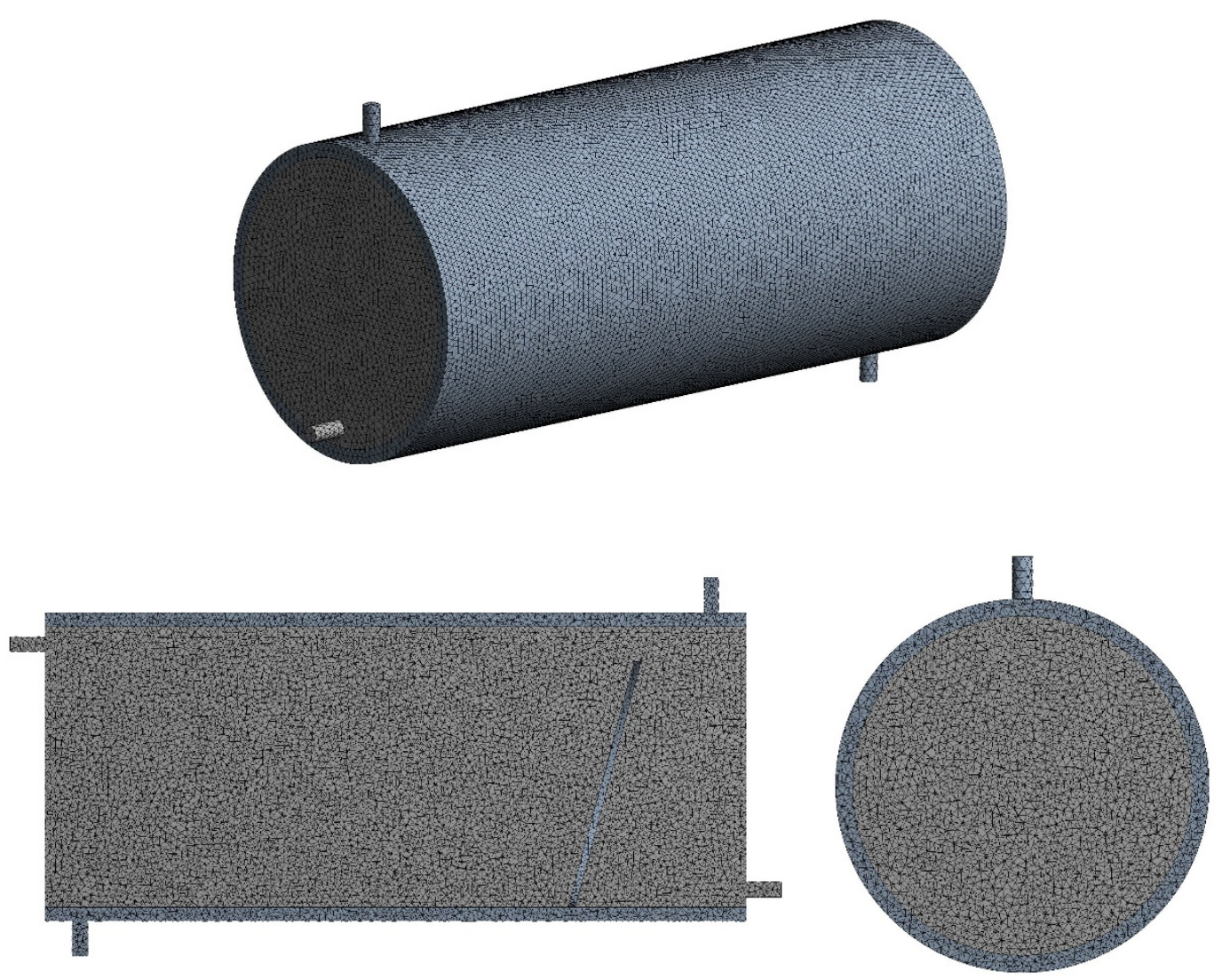

Şekil. 4. $\mathrm{a}=75^{\circ} \mathrm{m}=150 \mathrm{~mm}$ olan durum için ağ yapısı

\subsection{Sayısal Prosedür}

Sayısal çözümlemelerde FLUENT 17.1 programı kullanılarak 3 boyutlu ve zamana bağlı olarak gerçekleştirilmiştir. Sayısal çözümlemeler 120 dakikalık bir periyot için yapılmıştır. Zamana bağlı çözümlemelerde zaman adımının sonuçlar üzerindeki önemli etkisi vardır. Bu kapsamda, sonuçları zaman adımının büyüklüğünden bağımsızlaştırmak için $2,1,0.5$ ve $0.25 \mathrm{~s}$ zaman adımları sırası ile denenmiştir. $0.5 \mathrm{~s}$ zaman adımından sonra sonuçlarda önemli bir değişiklik olmadığından; zaman adımı $0.5 \mathrm{~s}$ olarak ayarlanmıştır. Manto ve şebeke girişleri "velocity inlet", manto ve kullanım suyu çıkışları ise "pressure outlet" olarak tanımlanmıştır. Tanktan 1Sı kaybı olmadığı yani tank dış yüzeylerinin adyabatik olduğu kabul edilmiştir. Manto ve iç tank içerisindeki akıştaki türbülans etkilerini hesaplamak için k-epsilon, k-epsilon RNG, k-w ve k-w SST türbülans modelleri denenmiştir. Bu modeller içerisinde en iyi ve en hızlı çözüm k-w türbülans modeli ile elde edilmiştir. Dolayısıyla analizler sırasında k-w türbülans modeli kullanılmıştır. Sayısal çözümlemelerde Simple algoritması kullanılmıştır. Bu çalışmada 
geliştirilen sayısal model ve prosedür yöntemi, engelsiz tank için yapılan deneysel çalışma sonuçları ile kıyaslanmıştır. Böylece sayısal model ve prosedürün yatay mantolu bir sıcak su tankını modellemede yeterli olup olmadığı kontrol edilmiştir.

\subsection{Termodinamik Analizler}

Literatürde düşey sıcak su tanklarının isıl performansını değerlendirmek için çok sayıda yol ve yöntem bulunmaktadır. Bu doğrultuda çok sayıda boyutlu ve boyutsuz sayı ya da ifadeler geliştirilmiştir. Ancak yatay sıcak su tankları ile alakalı böyle ifade ya da parametre bulunmamaktadır. Bu sebepten dolayı, en iyi engel konumunu ve açısını belirlemek için termodinamik analizler kullanılmıştır. Termodinamik analizler kapsamında, her bir durum için enerji ve ekserji analizi yapılmıştır. Böylece en yüksek enerji ve ekserji verimine sahip durum belirlenmeye çalışılmıştır. Termodinamik analizler sırasında hesaplamaların karmaşıklığını azalmak ve sistem açısından önemli olan parametrelerin etkisi daha belirgin bir şekilde incelemek için bazı kabuller yapılmıştır. Bu kabuller enerji ve ekserji verimini artıırsa da farklı durumlar arasındaki bağıl değişimi önemli ölçüde etkilememektedir. Yapılan kabuller aşağıda sıralanmıştır.

- Akışkanlar sıkıştırılamazdır.

- Akışkanların termofiziksel özellikleri sabit olarak alınmıştır.

- Akışkanlar sürtünmesizdir ve pompa gücü sıfirdır.

- Tanktan çevreye olan 1sı kayıpları ihmal edilmiştir.

- Çevre sıcaklığ $24{ }^{\circ} \mathrm{C}$ olarak alınmıştır.

Enerji analizi: Yatay mantolu bir sıcak su tankı için enerji dengesi aşağıdaki gibi yazılabilir.

$$
\text { Giren enerji - Çıkan enerji }=\text { Sistemdeki değişim }
$$

Bu ifade aşağıdaki gibi yazılabilir:

$$
\left(\dot{E}_{A}-\dot{E}_{B}\right)-\left[\left(\dot{E}_{D}-\dot{E}_{C}\right)-\dot{E}_{\text {kayıp }}\right]=\Delta \mathrm{E}
$$

Buradaki ifade de $\left(\dot{E}_{A}-\dot{E}_{B}\right)$ ifadesi iç tanka giren 1sı enerji miktarıyken, $\left(\dot{E}_{D}-\dot{E}_{C}\right)$ ifadesi ise tanktan alınan 1S1 enerjisi miktarıdır. Termodinamik verimin en gelen anlamda bir sistemden alınan enerjinin, bu enerjiyi almak için sağlanan enerjiye oranı olduğu dikkate alınarak; yatay mantolu sıcak su tankı için enerji verimi;

$$
\eta=\frac{\left(\dot{E}_{D}-\dot{E}_{C}\right)-\dot{E}_{\text {kayıp }}}{\left(\dot{E}_{A}-\dot{E}_{B}\right)}
$$

ifadesi ile hesaplanır. Tankın her bir giriş ve çıkışındaki enerji miktarı aşağıdaki gibi hesaplanır.

$$
\dot{E}_{i}=\dot{m} c\left(T_{i}-T_{\text {ortam }}\right)
$$

Bu ifadedeki “i” tankın her hangi bir giriş ya da çıkışını temsil etmektedir.

Ekserji analizi: Yatay mantolu bir sıcak su tankı için ekserji dengesi aşağıdaki gibi yazılabilir.

$$
\text { Giren ekserji - (Çılkan ekserji + Isı kaybı ekserjisi }) \text { - Ekserji yokoluşu = Sistemdeki değișim }
$$

Bu ifade aşağıdaki gibi yazılabilir:

$$
\left(\dot{E} x_{A}-\dot{E} x_{B}\right)-\left[\left(\dot{E} x_{D}-\dot{E} x_{C}\right)-\dot{E} x_{k a y \imath p}\right]-\dot{I}=\Delta \mathrm{Ex}
$$

Bu ifadedeki $\left(\dot{E} x_{A}-\dot{E} x_{B}\right)$ depolama hacmine giren ekserji miktarın temsil etmektedir. $\left(\dot{E} x_{D}-\dot{E} x_{C}\right)$ ifadesi depolama hacminden alınan net ekserji miktarını göstermektedir. $(\dot{I})$ ise yatay mantolu sıcak su tankının içerisindeki tersinmezliklerden kaynaklanan yok olan ekserji miktarını temsil etmektedir.

Yatay mantolu sıcak su tankı için ekserji verimi ifadesi aşağıdaki gibi yazılabilir.

$$
\psi=\frac{\left(\dot{E} x_{D}-\dot{E} x_{C}\right)-\dot{E} x_{k a y \imath p}}{\left(\dot{E x_{A}}-\dot{E} x_{B}\right)}
$$

Tankın giriş ve çıkışlarında ekserji değerleri aşağıdaki ifade ile hesaplanabilir. 


$$
\dot{E x_{i}}=\dot{m} c\left[\left(T_{i}-T_{\text {ortam }}\right)-T_{\text {ortam }} \ln \frac{T_{i}}{T_{\text {ortam }}}\right]
$$

\section{BULGULAR VE TARTIŞMA}

\subsection{Sayısal Model ve Prosedürün Doğrulanması}

Sayısal çözümlemeler yapılmadan önce ilk olarak sayısal modelin ve prosedürün doğrulanması gerekmektedir. Bu çalışmada Erdemir ve Altuntop (2018)'in yapmış olduğu deneysel çalışmanın sonuçları kullanılmıştır. Sayısal doğrulama içerisinde engel olmayan normal tank için gerçekleştirilmiştir. Sayısal olarak hesaplanan sonuçlar ile deneysel sonuçların kıyaslanması Şekil 5'de görülmektedir. Şekil 5a'da tankın manto çıkış ve şebeke çıkış sıcaklıklarının zamana bağlı değişiminin sayısal çözümleme sonuçları ve deneysel sonuçları görülmektedir. Şekil 5a'dan görüldüğü üzere, sayısal model ve prosedür tank çıkış sıcaklıklarını zaman bağlı olarak hesaplamada başarılı olduğunu göstermektedir. Sayısal çözümleme sonuçları ve deneysel sonuçlar uyum içerisindedir. Şekil 5b'de ise tank içerisindeki sıcaklık dağılımının 120 dakikalık test süresi sonundaki sayısal ve deneysel sonuçları görülmektedir. Şekil 5b'de I, II, III ... IX olarak numaralandırılan noktalar Erdemir ve Altuntop (2018)'in yapmış olduğu deneysel çalışmadaki sıcaklık sensörlerini göstermektedir. Şekil 5b'den görüldüğü üzere, bu çalışmada geliştirilen sayısal model ve prosedür tank içerisindeki sıcaklık dağılımını hesaplamada iyi bir performans göstermiştir. Sonuç olarak, sayısal model ve prosedür tank içerisindeki sıcaklık dağılımını ve çıkış sıcaklıklarını hesaplamada yeterlidir.

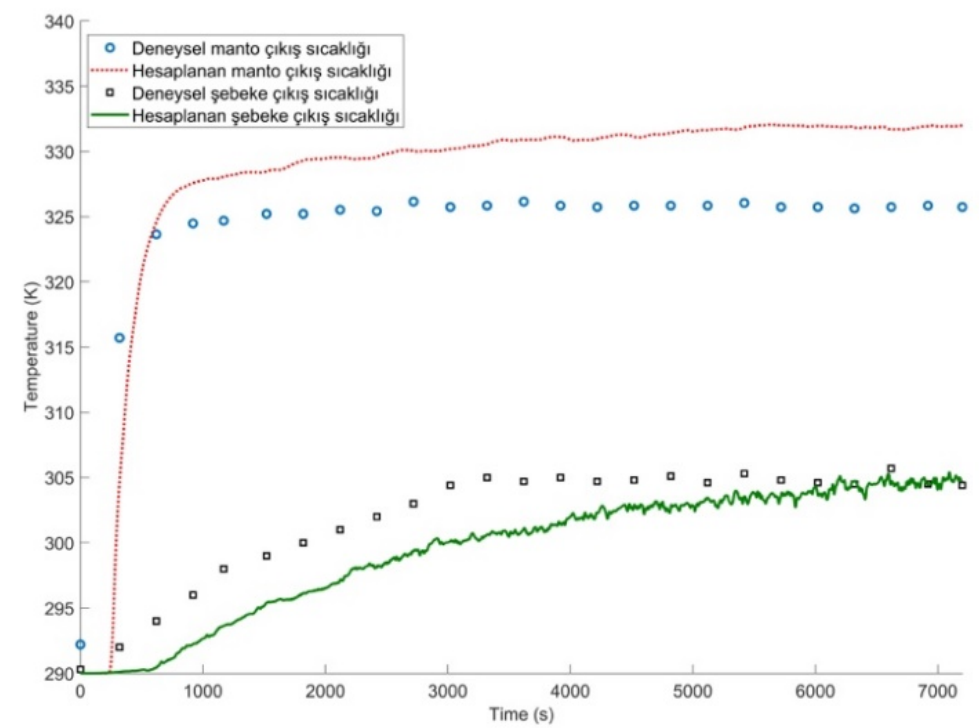

(a)

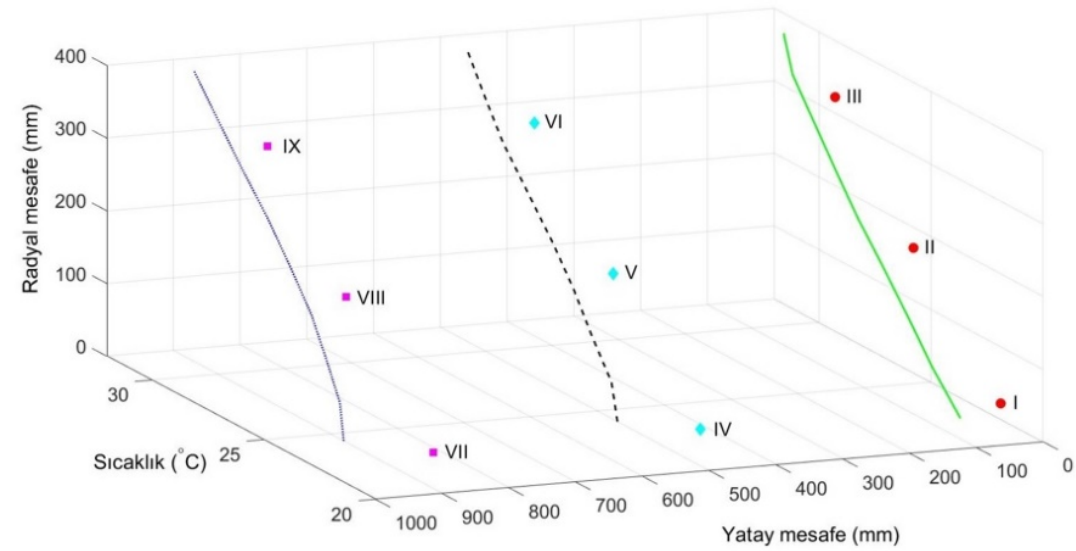

(b)

Şekil. 5. Sayısal çözümleme sonuçlarının deneysel çalışma sonuçları ile kıyaslanması a) Manto çıkış ve şebeke çıkış sıcaklarının zamanla değişimi, b) Tank içerisindeki sıcaklık dağılımı

\subsection{Eğik Engel Yerleştirmenin Tank İçerisindeki Sıcaklık Dağılımı Üzerindeki Etkisi}

Bir sıcak su tankının 1sıl performansını değerlendirmede tank içerisindeki sıcaklık dağılımını kullanmak temel, basit ve hızlı yöntemler biridir. Çünkü tank içerisindeki suyun sıcaklık seviyesini ve depolanan sıcak suyun miktarını direk olarak göstermektedir. Bir sıcak su depolama tankında mümkün olarak en yüksek sıcaklıkta ve hacimde suyun depolanması istenmektedir. Tank içerisindeki sıcaklık dağılımı ise bu bilgileri direk olarak sunmaktadır. 120 dakikalık test süresi sonunda, normal tank ve içerisindeki engel bulunan tanklar için sıcaklık dağılımı Şekil 6'da görülmektedir. Şekil 6'dan görüldüğü üzere, 
tank içerisinde engel olmayan durumda şebekeden gelen soğuk su tank içerisinde hızla ilerleyerek kullanım suyu çıkışına ulaşmıştır. Bu durum kullanım suyu sıcaklı̆ıını önemli ölçüde düşürmektedir. Engel yerleştirilen durumlarda şebekeden gelen soğuk su engeller tarafindan bloke edilmiştir. Böylece engelden sonraki kısımlarda yüksek sıcaklıkta ve hacimde sıcak su elde edilmiştir. Tankın içerisindeki engel olmayan durumda, tankın alt kısmı şebekeden gelen soğuk suyun etkisi altında kalmıştır. Dik yerleştirilen engellerde engel bitiği konumdan hemen sonra bir soğuk su bölgesi oluşmaktadır. Bu soğuk su bölgesi engeli eğimli yerleştirme ile azalmıştır. Engel açısı düştükçe engelin art kısmında olan soğuk su bölgesi azalmıştır. Ayrıca dik engelin şebeke girişinden olan mesafe azaldıkça engelin ardında kalan soğuk su bölgesinin hacmi de artmıştır. Benzer durum eğik yerleştirilmiş durumlarda da görülmüştür. Eğik yerleştirilmiş engellerde en az soğuk su bölgesi engelin $100 \mathrm{~mm}$ olduğu durumlarda görülmektedir. Sonuç olarak 120 dakika sonunda tank içerisindeki sıcaklık dağılımı göz önünde bulundurulduğu zaman, eğik engel kullanmanın ve engelin tank girişinden $100 \mathrm{~mm}$ mesafe de konumlandırılması tank içerisindeki sıcaklık dağılımı olumlu yönde etkilemektedir.

\subsection{Tank İçerisine Eğik Engel Yerleştirmenin Ortalama Depolanmış Su Sıcaklı̆ğ Üzerindeki Etkisi}

Bir sıcak su tankında depolanan suyun ortalama sıcaklığı oldukça önemlidir ve depolanan suyun sıcaklı̆̆ının en yüksek seviyede olması istenir. Tek başına sıcak su miktarı ile ilgili bilgi vermese de tankın içerisindeki sıcaklık dağılımı ile sistem performansını değerlendirme de önemli bilgiler vermektedir. Şekil 7'da tank içerisinde depolanan sıcak suyun sıcaklığının zamanla değişimi tüm durumlar için görülmektedir. Şekil 7'dan görüldüğü üzere, ortalama depolanan su sıcaklığı en düşük normal tankta görülmüştür. Tank içerisinde engel kullanmak tank içerisinde depolanan suyun ortalama sıcaklığını arttırmıştır. En yüksek ortalama depolanan su sicaklığ $1 \mathrm{a}=90^{\circ} \mathrm{m}=50 \mathrm{~mm}$ durumu, $\mathrm{a}=75^{\circ} \mathrm{m}=100 \mathrm{~mm}$ durumu ve $\mathrm{a}=60^{\circ} \mathrm{m}=100 \mathrm{~mm}$ durumunda görülmüştür. İçerisinde engel olmayan tanka göre depolanan su sıcaklığı yaklaşık $3.5^{\circ} \mathrm{C}$ yüksektir. Eğik engelin $\mathrm{m}=100 \mathrm{~mm}$ olduğu konumlarda en yüksek depolama sıcaklıkları görülmüştür. Şekil 7'den elde edilen bulgular Şekil 6'daki sicaklık dağılımdan elde edilen bulgular ile kıyaslandığı zaman, eğik engel kullanmak ve bu engeli şebeke girişinden $\mathrm{m}=100 \mathrm{~mm}$ pozisyonunda konumlandırmak tank içerisinde en yüksek miktarda ve sıcaklıkta su depolamayı sağlamaktadır. Belirtilen şartlarda engel kullanımı ile hem sistemin 1sıl enerji depolama performansı hem de kullanıcı memnuniyeti artacaktır.

\subsection{Tank İçerisine Eğik Engel Yerleştirmenin Manto Çıkış ve Kullanım Suyu Sıcaklığı Üzerinki Etkisi}

Manto çıkış sıcaklı̆ğ ve şebeke çıkışs sıcaklığı mantolu sıcak su tankları için önemli performans parametrelerindendir. Manto çıkış sıcaklığı sıcak su tankının ve kolektörün 1sıl verimi açısından önemlidir. Düşük manto çıkış sıcaklığı mantolu 1S1 değiştiricinin ve kolektörlerin verimini arttırır. Ayrıca daha yüksek sıcaklık değişimi suyun yoğunluğunu da daha fazla değiştireceğinden doğal sirkülasyonun hızını da arttırmaktadır. Bu sebeplerden dolayı manto çıkış sıcaklığının genellikle mümkün olan düşük seviyede olması istenir. Kulanım suyu çıkış sıcaklığı ise direk olarak kullanıcı memnuniyeti ile alakalıdır. Kullanıcılar mümkün olan yüksek sıcaklıkta ve miktarda sıcak su istemektedirler. Şekil 8'de 120 dakikalık test süresi sonundaki

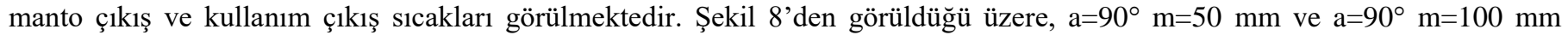
durumları haricindeki tüm engel yerleştirilmiş durumlar manto çıkış sıcaklığını düşürmüş, şebeke çıkış sıcaklığını ise arttırmıştır. En yüksek şebeke çıkış sıcaklığ $\mathrm{a}=75^{\circ} \mathrm{m}=150 \mathrm{~mm}$ ve $\mathrm{a}=60^{\circ} \mathrm{m}=150 \mathrm{~mm}$ olduğu durumlarda görülmüştür. Yine bu durumlarda en düşük manto çıkış sıcaklıkları elde edilmiştir. Bu bulgulardan yola çıkarak, tank içerisinde eğimli engel yerleştirmenin manto çıkış ve şebeke çıkış sıcaklıkları göz önünde bulundurarak daha yüksek performans sağladığı tespit edilmiştir. Eğimli engeller ile kullanım suyu sıcaklığı yaklaşık $3{ }^{\circ} \mathrm{C}$ 'ye arttırılabilirken, manto çıkış sıcaklığı ise yaklaşık $3{ }^{\circ} \mathrm{C}^{\prime}$ ye kadar düşürülebilir.

\subsection{Tank İçerisine Eğik Engel Yerleştirmenin Termodinamik Açıdan Değerlendirilmesi}

Enerji depolama ve enerji dönüşüm sistemlerinde sistemin performansını belirlemede termodinamik analizler yaygın olarak kullanılmaktadır. Literatürdeki çalışmalarda enerji analizinin sistemi kıyaslamada belirgin bilgiler vermediği bu yüzden sistemlerin ekserji yönünden de değerlendirilmesi gerektiği görülmektedir. Ancak enerji analizinin sistemi tanımada, sistemin giriş ve çıkışlarındaki değişimleri gözlemlemede ve sistem ile çevresi arasındaki etkileşimi belirlemede önemli olduğu vurgulanmıştır. Literatürdeki çalışmalar göz önünde bulundurularak, bu çalışmada normal tank ile içerisine engel yerleştirilmiş tankların kıyaslaması termodinamiğin birinci ve ikinci kanun analizleri gerçekleştirilmiştir. 120 dakikalık test süresinin sonunda elde edilen veriler ile tüm durumlar için enerji ve ekserji verimi değerleri Şekil 9'da görülmektedir. Şekil 9'dan görüldüğü üzere, enerji verimi normal tank için \%96'dır. İçerisindeki engel bulunan durumlarda \%96.5 ile \%99.5 arasında değişmektedir. Enerji verim ifadelerinden tüm durumların ideale yakın davranış sergilediği görülmektedir. Ayrıca enerji verimi tank içerisine engel yerleştirme ile \%3 civarında artmıştır. İçerisinde engel yerleştirilen durumlarda enerji verimi ifadeleri birbirine yakın olduğundan dolayı durumları enerji verimlilik üzerinden doğru bir şekilde kıyaslanamamaktadır. Yatay mantolu sıcak su tankının tüm durumlardaki ekserji verimi değerleri incelenecek olursa, ekserji veriminin normal tank için yaklaşık \%8 olduğu görülmektedir. İçerisinde engel bulunan tüm durumların ekserji verimi değeri normal tanka göre yüksektir. En yüksek ekserji verimi değeri eğim açısının $60^{\circ}$ ve engel pozisyonunun 100 ve $150 \mathrm{~mm}$ olduğu durumda görülmüştür. Enerji ve ekserji verimi ifadeleri göz önünde bulundurulduğu zaman, tank içerisinde engel bulunmak termodinamik açıdan sistemi iyileştirmiştir. Eğimli yerleştirilmiş engeller dik engellere göre daha yüksek ısıl performans sağlamışlardır. 
Normal Tank

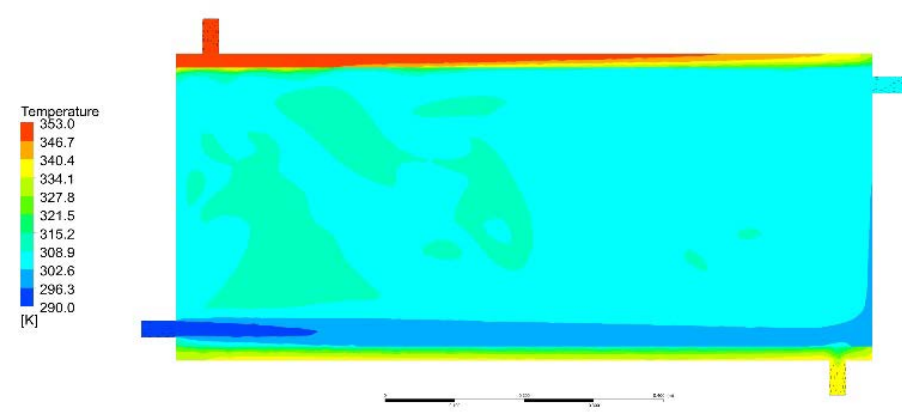

$\mathrm{a}=90^{\circ} \mathrm{m}=100 \mathrm{~mm}$

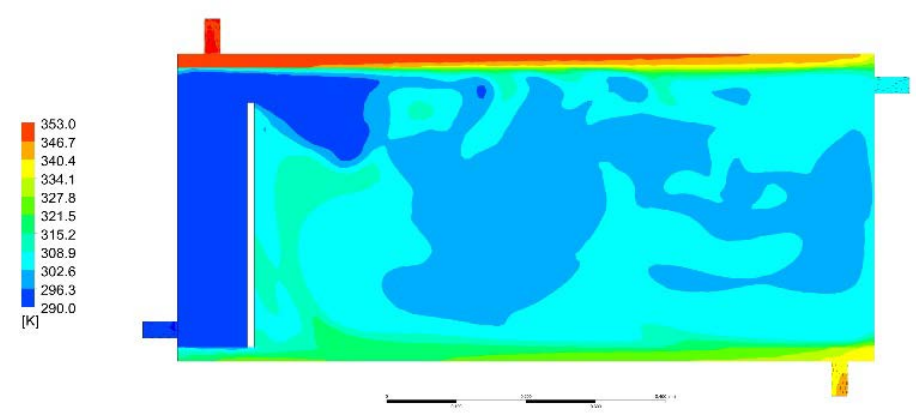

$\mathrm{a}=75^{\circ} \mathrm{m}=50 \mathrm{~mm}$

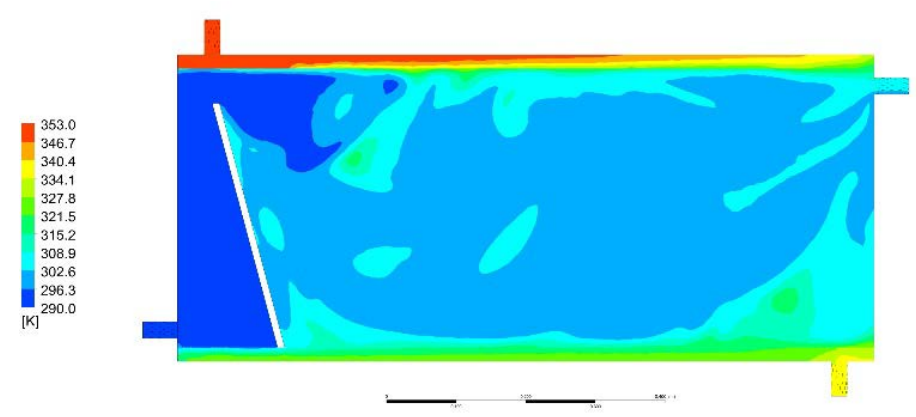

$\mathrm{a}=75^{\circ} \mathrm{m}=150 \mathrm{~mm}$

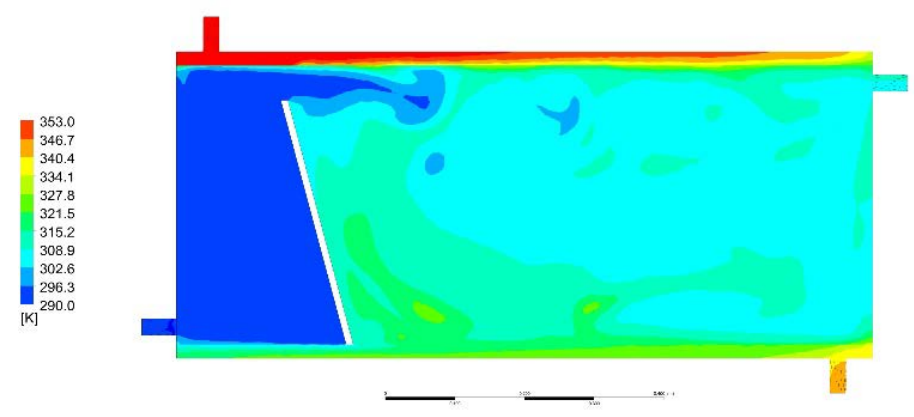

$\mathrm{a}=60^{\circ} \mathrm{m}=100 \mathrm{~mm}$

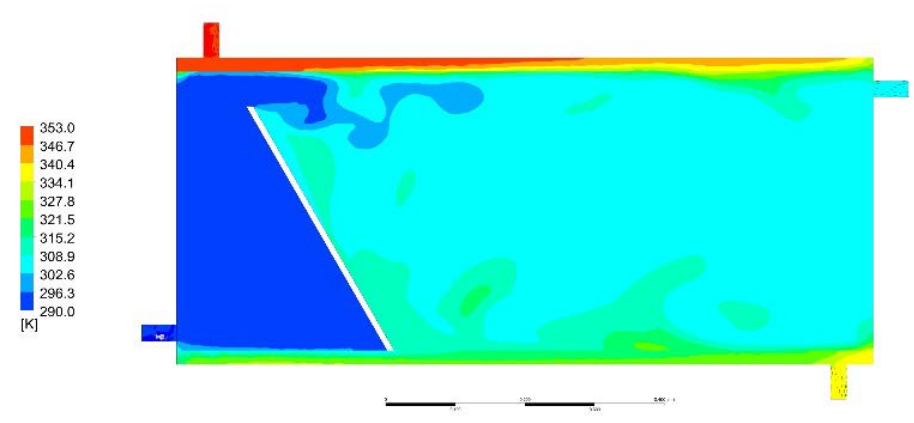

$\mathrm{a}=90^{\circ} \mathrm{m}=50 \mathrm{~mm}$

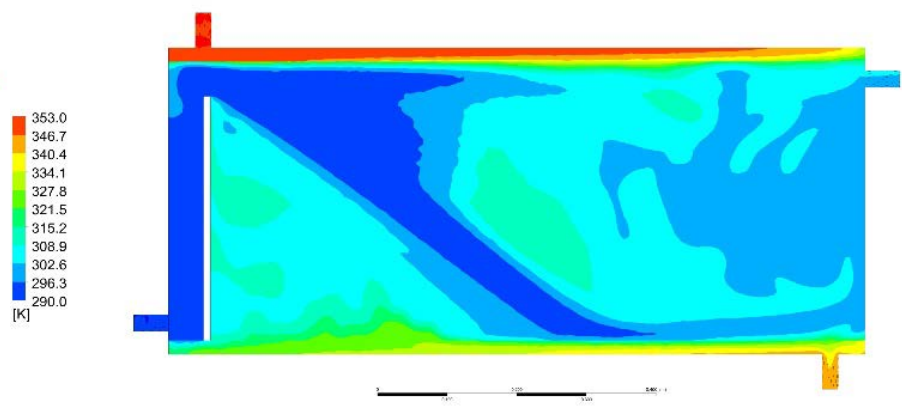

$\mathrm{a}=90^{\circ} \mathrm{m}=150 \mathrm{~mm}$

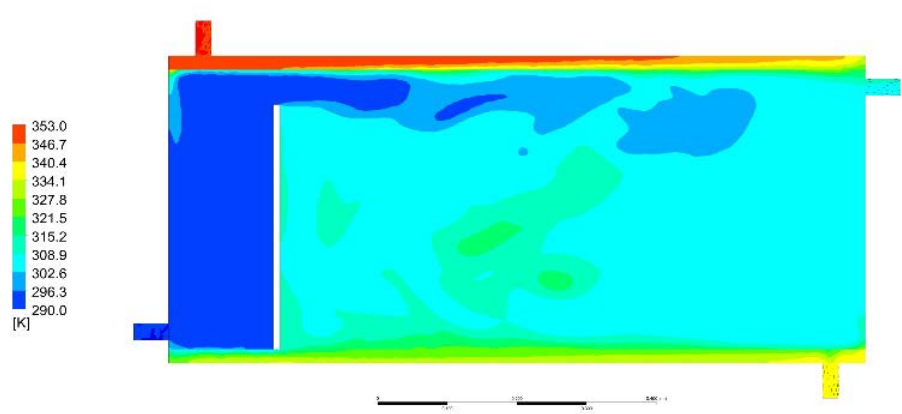

$\mathrm{a}=75^{\circ} \mathrm{m}=100 \mathrm{~mm}$

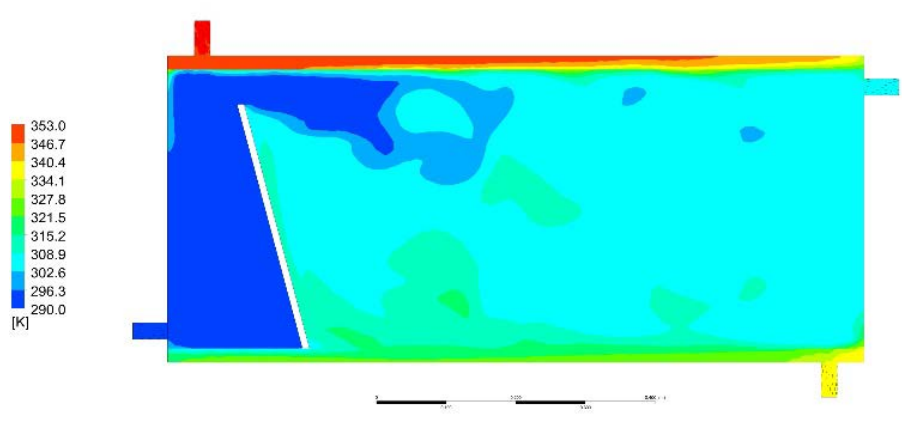

$\mathrm{a}=60^{\circ} \mathrm{m}=50 \mathrm{~mm}$

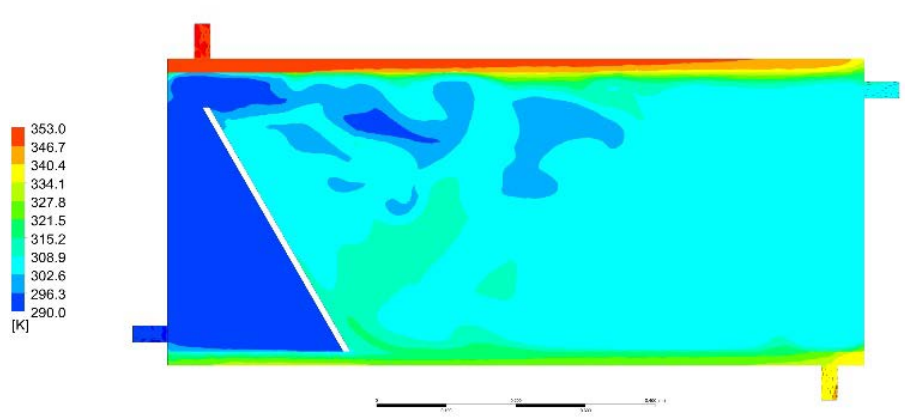

$\mathrm{a}=60^{\circ} \mathrm{m}=150 \mathrm{~mm}$

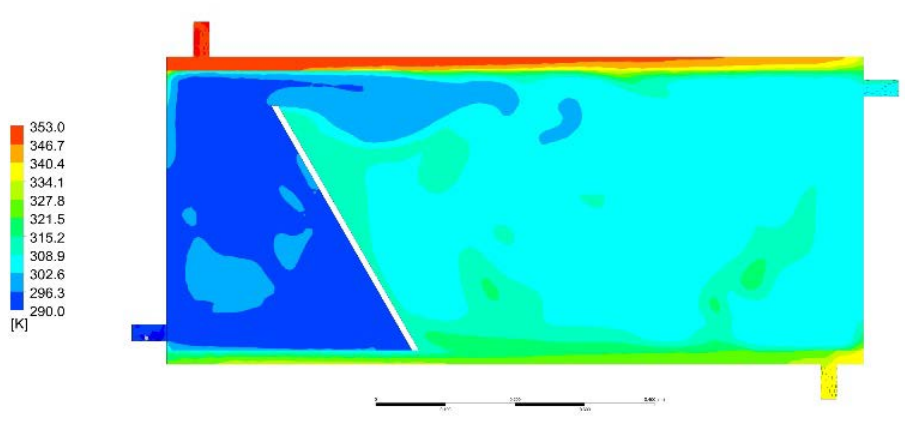

Şekil. 6. Tüm durumlar için 120 dakika sonundaki sıcaklık dağılımları 


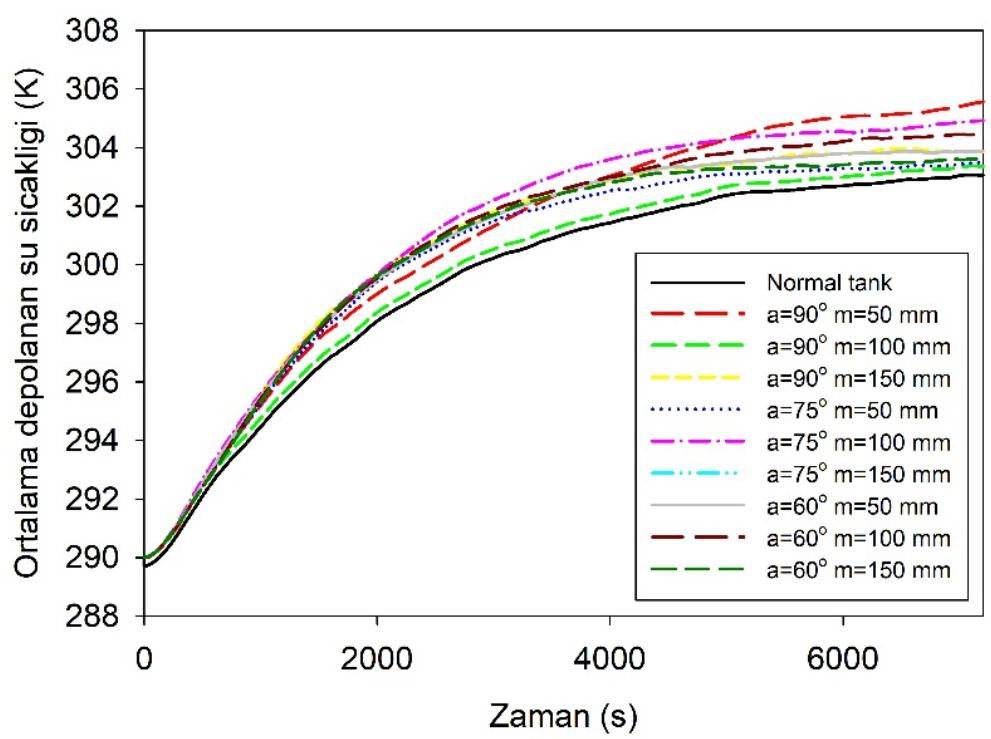

Şekil. 7. Tüm durumlar için ortalama depolanan su sıcaklığının zamanla değişimi

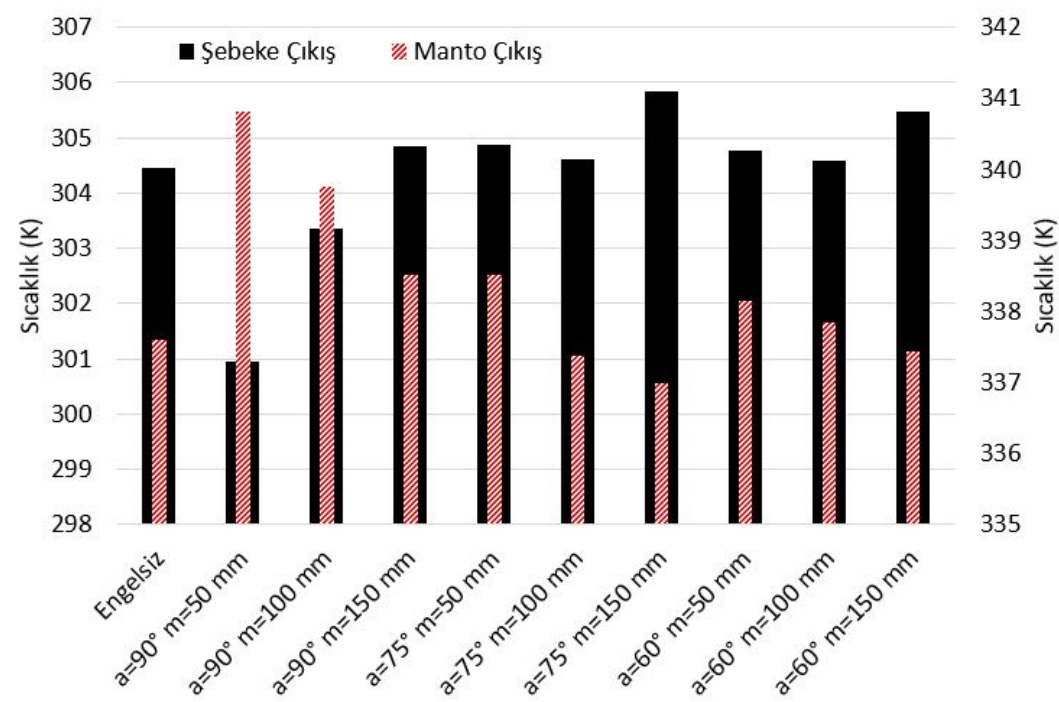

Şekil. 8. Tüm durumlar için manto çıkış ve şebeke çıkış sıcaklıklarının 120 dakika sonundaki değeri

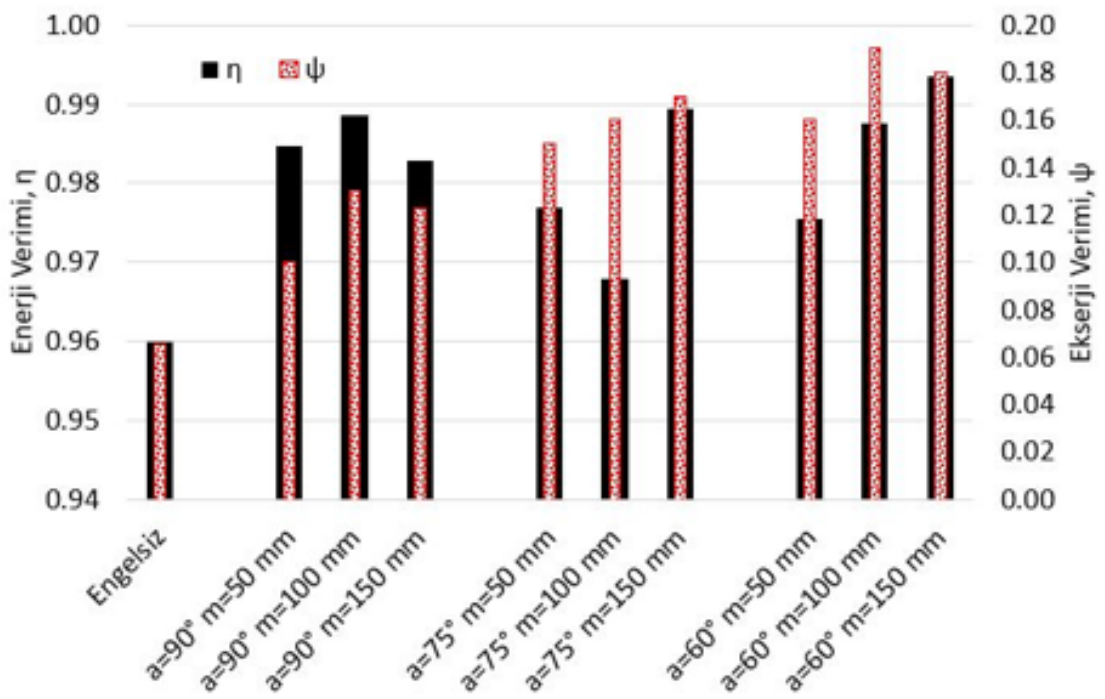

Şekil. 9. Tüm durumlar için 120 dakika sonundaki enerji ve ekserji verimi değerleri 


\section{SONUÇLAR}

Bu çalışmada, yatay mantolu sıcak su depolama tanklarındaki tank içerisinde eğimli engel yerleştirmenin etkisi sayısal olarak araştırılmıştır. Eğimli engelin sağladığı 1sıl performans, dik yerleştirilmiş engelin sağladığı performans ve normal tank ile kıyaslanmıştır. Çalışmada 10 farklı durum için 120 dakikalık sayısal çözümleme yapılmıştır. Sayısal çözümlemelerden elde edilen bulgular tank içerisindeki sıcaklık dağılımı, tank içerisindeki depolanan suyun ortama sıcaklığı, manto çıkış sıcaklığı, şebeke çıkış sıcaklığı, enerji ve ekserji verimliliği üzerinden değerlendirilmiştir. Çalışmanın sonucunda, tank içerisine engel yerleştirmenin tankın 1sıl performansını arttırdığı ve engel eğik olarak yerleştirmenin dik olarak yerleştirmeye göre daha yüksek performans sağladığı tespit edilmiştir. Tüm değerlendirme parametreleri göz önünde bulundurulduğu zaman engel açısının $75^{\circ}$ pozisyonunun ise tank girişinden $100 \mathrm{~mm}$ mesafede olması gerektiği bulunmuştur. Böylece depolana su sıcaklığının $3^{\circ} \mathrm{C}^{\prime}$ 'ye kadar artabileceği, manto çıkış sıcaklığının $5{ }^{\circ} \mathrm{C}$ kadar düşebileceği, şebeke çıkış sıcaklığının $3{ }^{\circ} \mathrm{C}$ ye kadar artacağı ve ekserji veriminin yaklaşı \%10 artabileceği bulunmuştur.

\section{TEŞEKKÜRLER}

Bu çalışma KOSGEP tarafından ARGE ve İnovasyon Destek Programları kapsamında 03.05.2017 tarihli 657 nolu kurul kararı ile desteklenmiştir.

\section{REFERANSLAR}

Acar, C. (2018). A comprehensive evaluation of energy storage options for better sustainability. International Journal of Energy Research, 1-15. Available online. 2018.Doi:10.1002/er.4102.

Alizadeh, S. (1999). An experimental and numerical study of thermal stratification in a horizontal cylindrical solar storage tank. Solar Energy, 66 (6), 409-421.

Andres A.C., Lopez M.C. (2002). TRNSYS model of a thermosiphon solar domestic water heater with a horizontal storage and mantle heat exchanger. Solar Energy. 72 (2). 89-98.

Arslan, G., Yaman, K. (2017). The optimization of solar water heating system using hybrid algorithm (PSO/HJ) for different locations of Turkey. Uluslararası Mühendislik ve Araştırma Geliştirme Dergisi. 9(3). 73-82. DOI: 10.29137/umagd.346154.

Atmane, M.A., Chan, V.S.S., Murray, D.B. (2003). Natural convection around a horizontal heated cylinder: The effects of vertical confinement. International Journal of Heat and Mass Transfer. 46(19). 3661-3672.

Erdemir, D., Altuntop N. (2018). Experimental Investigation on the effect of placing obstacle on flow direction on thermal performance in horizontal mantled hot water tanks, Proc. of 4th Anatolian Energy Symposium, Edirne, Turkey, 1993-2002.

Erdemir, D. (2018). Numerical Investigation on The Effect of Ratio of Tank Diameter to Tank Length on The Thermal Performance of Horizontal Mantled Hot Water Tank, Heat Transfer Research, Accepted paper, DOI: 10.1615/HeatTransRes.2018026953.

Fertahi, S., Bouhal, T., Kousksou, T., Jamil, A., Benbassou, A. (2018). Experimental study and CFD thermal assessment of horizontal hot water storage tank integrating Evacuated Tube Collectors with heat pipes. Solar Energy. (170). 234-251.

Helwa, N.H., Mobarak A.M., ESallak M.S., EGhetany H.H. (1995). Effect of hot-water consumption on temperature distribution in a horizontal solar water storage tank. Applied Energy. 52. 185-197.

Jannatabadi, M. (2012). An experimental study of hot water onsumtion on the thermal performance of a horizontal mantle tank. 19 (9). 1332-1326.

Jannatabadi, M., Taherian, H. (2012). An experimental study of influence of hot water consumption rate on the thermal stratification inside a horizontal mantle sotrage tank. 48. 1103-1112.

Kalogirou, S.A., Papamarcou, C. (2000). Modelling of a thermosyphon solar water heating system and simple model validation. Renewable Energy. 21(3). 471-493.

Khalifa A.N., Mehdi, M.M. (1999). On the verification of one dimensional heat flow in a horizontal thermosyphon storage tank. Energy Conversion and Management. 40. 961-974.

Liu, W., Davidson, J.H., Kulacki, F.A., Mantell, S.C. (2002). Natural Convection from a Horizontal Tube Heat Exchanger Immersed in a Tilted Enclosure, Journal of Solar Energy Engineering. 125(1). 65-74.

Madhlopa, A., Mgawi, R., Taulo, J. (2005). Experimental study of temperature stratification in an integrated collector -storage solar water heater with two horizontal tanks. 80. 989-1002. 
Morrison G.L., Nasr, A., Behnia, M., Rosengarthen, G.(1998). Analysis of horizontal mantle heat exchangers in solar water heating systems. Solar Energy. 64. 19-31.

Morrison, G.L., Rosengarthen, G., Behnia, M. (1999). Mantle heat exchangers for horizontal tank thermosyphon solar water heaters. Solar Energy. 67. 53-64.

Rosengarten, G., Behnia, M., Morrison, G. (1999). Some aspects concerning modelling the flow and heat transfer in horizontal mantle heat exchangers in solar water heaters”, International Journal of Energy Research. 23. 1007-1016.

Rosengarten, G., Morrison, G.L., Behnia, M. (2001). Mixed convection in a narrow rectangular cavity with bottom inlet and outlet. Heat and Fluid Flow. 22. 168-179.

Tripanagnostopoulos, Y., Souliotis, M. (2004). ICS solar systems with horizontal (E-W) and vertical (N-S) cylindrical water storage tank, Renewable Energy. 29(1). 73-96.

Tripanagnostopoulos, Y., Souliotis, M. (2004). ICS solar systems with horizontal cylindrical storage tank and reflector of CPC or involute geometry. Renewable Energy. 29(1). 13-38, 2004.

Young, M.F., Baughn, J.W. (1981). An investigation of thermal stratification in horizontal storage tanks. 103. 286-290.

Zerrouki, A., Boumédien A., Bouhadef, K. (2002). The natural circulation solar water heater model with linear temperature distribution. Renewable Energy. 26(4). 549-559. 